medRxiv preprint doi: https://doi.org/10.1101/2020.04.06.20054114; this version posted April 11, 2020. The copyright holder for this preprint (which was not certified by peer review) is the author/funder, who has granted medRxiv a license to display the preprint in perpetuity.

It is made available under a CC-BY 4.0 International license.

\title{
A streamlined approach to rapidly detect SARS-CoV-2 infection, avoiding RNA purification
}

Stefania Marzinotto ${ }^{1}$, Catia Mio², Adriana Cifù ${ }^{2}$, Roberto Verardo ${ }^{3}$, Corrado Pipan ${ }^{1,2}$, Claudio Schneider ${ }^{2}$, Francesco Curcio ${ }^{1,2}$

${ }^{1}$ Department of Laboratory Medicine, ASU FC, Udine, Italy

${ }^{2}$ Department of Medicine (DAME), University of Udine, Udine, Italy.

${ }^{3} \mathrm{ClB}$-Consorzio Interuniversitario Biotecnologie (Interuniversity Consortium for Biotechnologies), Padriciano 9934012 Trieste

Correspondence to: Prof. Francesco Curcio

Department of Medicine (DAME)- University of Udine

Via Colugna 50,

33100 - Udine, Italy

francesco.curcio@uniud.it

Running title:

Conflict of Interest Statement: The authors have no conflicts of interest to declare.

Abstract

In the current pandemic, the presence of SARS-CoV-2 RNA in samples by nucleic acid (NA) molecular analysis is the only method available to diagnose COVID-19 disease and to assess patients' infectiveness. Recently, the demand for laboratory reagents has greatly increased; in particular, there is a worldwide shortage of RNA extraction kits. Here, we describe a fast, simple and inexpensive method for the detection of SARS CoV-2 RNA, which includes a pretreatment with Proteinase $\mathrm{K}$ and a heating-cooling cycle before the amplification. This method bypasses the RNA extraction step; it leads to a higher amount of available viral RNA compared to the automated extraction methods, and generates the same profile in the subsequent amplification phase. 
medRxiv preprint doi: https://doi.org/10.1101/2020.04.06.20054114; this version posted April 11, 2020. The copyright holder for this preprint (which was not certified by peer review) is the author/funder, who has granted medRxiv a license to display the preprint in perpetuity.

It is made available under a CC-BY 4.0 International license .

\section{Introduction}

Since the outbreak of the newly appeared severe acute respiratory syndrome coronavirus-2 (SARS-CoV-2) caused coronavirus disease (COVID-19), the demonstration of the virus presence by nasopharyngeal swabs and subsequent molecular analysis of viral Nucleic Acid (NA) has been the preferred diagnostic method. Several NA automated analytical molecular systems are available, which, although having the advantage of obtaining a pure product of the highest quality, are expensive and greatly lengthen the analysis procedures. More importantly, recently the ability of manufacturers of reagents for molecular diagnostics to meet the increasing demand has progressively diminished. In particular, the main limitation is represented by the shortage of NA extraction kits. Since the demonstration of the virus in the samples is the only way to really indicate the patient' infectiveness, this shortage risks to greatly impair our ability to limit the spreading of the pandemic with tragic consequences. In addition, even when reagents are available, NA isolation represents a significant part of the analytical protocol; eliminating this step will increase the productivity of laboratories and decrease the cost of testing.

To solve the above-mentioned issues, we developed a procedure for the treatment of nasopharyngeal swab $(n=500)$ collected from patients with suspected SARS-CoV-2 infection which eliminates the need for the RNA extraction step.

\section{Materials and Methods}

\section{Automated RNA extraction from nasopharyngeal swab}

For nasopharyngeal swab collection, UTM $^{\circledR}$ tubes (COPAN Diagnostics) were used, i.e. plastic, screw cap tubes that maintains organism viability for 48 hours at room temperature or less. Those are FDA-approved systems suitable for collection, transportation and long-term storage $\left(-20^{\circ} \mathrm{C}\right)$ of clinical specimens. $200 \mu \mathrm{L}$ of medium from $3 \mathrm{~mL}$ of $\mathrm{UTM}^{\circledR}$ tube were used for automated RNA extraction with the ELITe InGenius ${ }^{\circledR}$ SP200 System (ELITechGroup), following manufacturer's instructions. Samples were eluted in $100 \mu \mathrm{L}$ elution buffer. Ethical approval was obtained from the Medical Research Ethics Committee of the Region Friuli Venezia Giulia, Italy (Consent CEUR-2020-Os-033).

RNA isolation from nasopharyngeal swab 
medRxiv preprint doi: https://doi.org/10.1101/2020.04.06.20054114; this version posted April 11, 2020. The copyright holder for this preprint (which was not certified by peer review) is the author/funder, who has granted medRxiv a license to display the preprint in perpetuity.

It is made available under a CC-BY 4.0 International license.

In a 96-well plate, $100 \mu \mathrm{L}$ of medium from $3 \mathrm{~mL}$ of $\mathrm{UTM}^{\circledR}$ tube were added to $10 \mu \mathrm{L}$ of $30 \mathrm{mg} / \mathrm{mL}$ Proteinase K from Tritirachium album (Sigma-Merck, catalog number P2308) in Hanks' Balanced Salt Solution (HBSS) w/ calcium and magnesium and w/o phenol red (Sigma-Merck, catalog number $55037 \mathrm{C}$ ). The plate was heated for $15 \mathrm{~min}$ at $55^{\circ} \mathrm{C}$, denatured for $5 \mathrm{~min}$ at $98^{\circ} \mathrm{C}$ and then placed for $2 \mathrm{~min}$ at $4^{\circ} \mathrm{C}$.

Quantitative Reverse Transcription Polymerase Chain Reaction (RT-qPCR)

LightMix ${ }^{\circledR}$ Modular SARS and Wuhan CoV E-gene (Roche, catalog number 53-0776-96) was used to compare the amplification of the E-gene in nasopharyngeal swab samples in which the RNA was purified by an automated system with those treated by the method developed by us. Briefly, $4 \mu \mathrm{L}$ Roche Master, $0.5 \mu \mathrm{L}$ Reagent mix (containing specific primers and probe following Corman et al. 2020) ${ }^{1}, 0.1 \mu \mathrm{L}$ RT enzyme, $5 \mu \mathrm{L}$ sample/positive control and nucleasefree water were mixed to a total volume of $15 \mu \mathrm{L}$. RT-qPCR was performed by the LightCycler ${ }^{\circledR}$ 480 II Instrument (Roche) and absolute quantification was assessed by the LightCycler ${ }^{\circledR} 480$ II System (Roche).

One-Step Reverse Transcription-Droplet digital Polymerase Chain Reaction (RT-ddPCR)

5' 6-FAM/3' BHQ-1 ${ }^{\circledR}$-conjugated $E-$-gene ${ }^{1}$ (Sigma Merck) was used for viral load assessment by the One-Step RT-ddPCR Advanced Kit for Probes (Bio-Rad, catalog number 186-4021). Briefly, $5 \mu \mathrm{L}$ of ddPCR ${ }^{\mathrm{TM}}$ Supermix for Probes (No dUTP), $900 \mathrm{nM}$ primers and $250 \mathrm{nM}$ probes, $15 \mathrm{mM}$ DTT, 20U/ $\mu \mathrm{L}$ Reverse Transcriptase, $5 \mu \mathrm{L}$ sample and nuclease-free water were mixed and brought to a total volume of $20 \mu \mathrm{L}$. Samples were mixed with Droplet Generator Oil for Probes (Bio-Rad, catalog number 1863005) and droplets were generated on the automated droplet generator QX200 ${ }^{\text {TM }}$ Droplet Generator (Bio-Rad). PCR amplification was performed by the Veriti ${ }^{\circledR}$ Thermal Cycler (ThermoFisher Scientific) with annealing at $55^{\circ} \mathrm{C}$ and standard thermal cycling conditions. Droplets were read on the QX200 ${ }^{\text {TM }}$ Droplet Reader (Bio-Rad) and reactions with less than $10^{\prime} 000$ droplets were repeated. Data were analyzed using the QuantaSoft ${ }^{\mathrm{TM}}$ 1.7.4 Software (Bio-Rad).

Statical analysis

The statistical analyses were performed with GraphPad Prism 6.0. Shapiro-Wilk test was performed to assess the normality of data distribution. Data are reported as mean \pm SD. Pearson's linear regression was performed to assess correlation between measurements. 
medRxiv preprint doi: https://doi.org/10.1101/2020.04.06.20054114; this version posted April 11, 2020. The copyright holder for this preprint (which was not certified by peer review) is the author/funder, who has granted medRxiv a license to display the preprint in perpetuity.

It is made available under a CC-BY 4.0 International license .

Paired Student's t test was performed to compare the two populations. ${ }^{*} p<0.05,{ }^{*} p<0.01$, $* * * p<0.001, * * * * p<0.0001$

\section{Results and Discussion}

A great number of nucleic acid extraction kits are used to prepare viral samples for analysis. In early 2020, Italy faced the exponential outbreak of SARS-CoV-2 infection originated in China and since declared a pandemic by the WHO, which highly impacted on the healthcare systems around the World and was responsible for tens of thousands of deaths. Molecular testing for SARS-CoV $-2^{2}$ is currently the best available approach for a correct diagnosis and to establish the infective potential of patients. RNA extraction from nasopharyngeal swabs of patients affected by COVID-19 has become a bottleneck in diagnostic procedures due to the enormous quantity of samples to be daily processed and to the shortage in extraction kit availability. In many instances, the shortage has induced the limitation of testing only to patients with symptoms (often non-specific) but in this way many asymptomatic or paucisymptomatic individuals ${ }^{3,4}$ have not been tested and have become a major vehicle by which the infection has spread, first in China ${ }^{5}$ and then in the rest of the World. To overcome this issue, we set up an in-house protocol to pretreat swab samples before performing RT-qPCR.

We compared results of the amplifications from automatedly extracted viral RNA with the swab-derived material treated as described in methods.

As shown in Figure 1, Panel A, both samples displayed the same amplification profile with minimal differences. To further validate our data, we employed a technique with higher sensitivity, the droplet digital PCR (ddPCR). Using samples from the automated extraction and from our method, we found the same viral copies (i.e. 13000 copies $/ 5 \mu \mathrm{L}$ ) in both, showing that our in-house pretreatment protocol is a reliable and rapid method to assess SARS-CoV-2 infection directly from nasopharyngeal swabs (Fig. 1; Panel B). Furthermore, since the automated diagnostic extraction system used in this study requires $200 \mu \mathrm{L}$ swab-derived material as template, while our method only needs $100 \mu \mathrm{L}$ of material, we were able to detect twice as much of the viral genome for each $\mu \mathrm{L}$ of sample.

Moreover, to assess correlation between our in-house RNA isolation method and the automated RNA extraction, linear regression was performed using RT-qPCR amplification data from 17 samples. Shapiro-Wilk's normality test was performed and, as shown in Figure 2, 
medRxiv preprint doi: https://doi.org/10.1101/2020.04.06.20054114; this version posted April 11, 2020. The copyright holder for this preprint (which was not certified by peer review) is the author/funder, who has granted medRxiv a license to display the preprint in perpetuity.

It is made available under a CC-BY 4.0 International license .

Pearson $r$ between the two groups was $0.9276(\mathrm{Cl} 95 \% 0,8066-0,9740, \mathrm{p}<0.0001)$ suggesting a high correlation between methodologies.

Considering the performance of our pretreatment protocol in generating a higher amount of viral RNA compared to the automated one, we tested its sensitivity in assessing viral copies with the two amplification methods (RT-qPCR and RT-ddPCR). We performed a 5-fold serial dilution of the same sample used in Figure 1 and assessed amplification curves in RT-qPCR. As shown in Figure 3, panel A, we were able to evaluate viral copies even in dilutions as high as 1:3125. To effectively assess how many actual viral copies our protocol is able to detect, we used the same approach using RT-ddPCR. As shown in Figure 3, panel B, our in-house protocol is able to detect as few as 10 SARS-CoV-2 copies directly from $5 \mu \mathrm{L}$ nasopharyngeal swabderived material.

These data allowed us to optimize the pretreatment protocol published by Fomsgaard and Rosenstierne ${ }^{6}$.

In conclusion, our treatment enables a SARS CoV-2 RNA amplification which is at least as sensitive and accurate as that performed with RNAs extracted using commercial kits. At this time of rapid spreading of COVID-19, the shortage of reagents for RNA extraction is significantly slowing down the testing process, which is the most effective way to contrast the pandemic. Our simple and fast protocol overcomes these limitations, bypassing the need for RNA extraction reagents, shortening the time of the analysis and reducing its cost.

\section{References}

1. Corman VM, Landt O, Kaiser M, Molenkamp R, Meijer A, Chu DK, Bleicker T, Brünink S, Schneider J, Schmidt ML, Mulders DG, Haagmans BL, et al. Detection of 2019 novel coronavirus (2019-nCoV) by real-time RT-PCR. Euro Surveill [Internet] 2020 [cited 2020 Mar 9];25. Available from: https://www.ncbi.nlm.nih.gov/pmc/articles/PMC6988269/

2. Wong JE, Leo YS, Tan CC. COVID-19 in Singapore-Current Experience: Critical Global Issues That Require Attention and Action. JAMA. 2020.

3. Xu T, Chen C, Zhu Z, Cui M, Chen C, Dai H, et al. Clinical features and dynamics of viral load in imported and non-imported patients with COVID-19. International Journal of Infectious Diseases. 2020.

4. Wong JE, Leo YS, Tan CC. COVID-19 in Singapore-Current Experience: Critical Global Issues That Require Attention and Action. JAMA. 2020.

5. Wang $\mathrm{Y}$, Kang $\mathrm{H}$, Liu $\mathrm{X}$, Tong Z. Combination of RT-qPCR Testing and Clinical Features For Diagnosis of COVID-19 facilitates management of SARS-CoV-2 Outbreak. Journal of Medical Virology. 2020. 
medRxiv preprint doi: https://doi.org/10.1101/2020.04.06.20054114; this version posted April 11, 2020. The copyright holder for this preprint (which was not certified by peer review) is the author/funder, who has granted medRxiv a license to display the preprint in perpetuity. It is made available under a CC-BY 4.0 International license.

6. Fomsgaard AS, Rosenstierne MW. An alternative workflow for molecular detection of SARS-CoV-2 - escape from the NA extraction kit-shortage [Internet]. Public and Global Health, $2020 \quad$ [cited 2020 Apr 4]. Available from: http://medrxiv.org/lookup/doi/10.1101/2020.03.27.20044495 
medRxiv preprint doi: https://doi.org/10.1101/2020.04.06.20054114; this version posted April 11, 2020. The copyright holder for this preprint (which was not certified by peer review) is the author/funder, who has granted medRxiv a license to display the preprint in perpetuity.

It is made available under a CC-BY 4.0 International license .

\section{Figure Legends}

Figure 1. Comparison between automated RNA extraction and in-house RNA isolation.

Patient's sample processed either with automated extraction or the in-house optimized procedure. A, the same amplification efficiency (average $22.5 \mathrm{Cp}$ ) was observed despite the diverse amount of swab-derived medium used for extraction/isolation $(200 \mu \mathrm{L}$ automated extraction vs $100 \mu \mathrm{L}$ custom protocol) in RT-qPCR. B, the same viral load (average 13000 copies) was observed in both samples by RT-ddPCR. In the figure, one representative amplification profile is shown.

Figure 2. Correlation between in-house RNA isolation and automated RNA extraction.

Scatter plot with linear regression (left panel) between the two methodologies tested. Black line represents the best-fit regression line. Box plot (right panel) representing the mean \pm SD of $\mathrm{N}=17$ samples treated with the two methodologies and amplified by RT-qPCR. $* * * * p<0.0001$.

Figure 3. Serial dilution of viral RNA isolated with the in-house method.

5-fold serial dilutions of a patient's sample isolated with the novel custom protocol (a-f). NTC was used to test sensitivity of both RT-qPCR (A) and RT-ddPCR (B). 
medRxiv preprint doi: https://doi.org/10.1101/2020.04.06.20054114; this version posted April 11, 2020. The copyright holder for this preprint (which was not certified by peer review) is the author/funder, who has granted medRxiv a license to display the preprint in perpetuity.

It is made available under a CC-BY 4.0 International license .

A

\section{Amplification Plot}

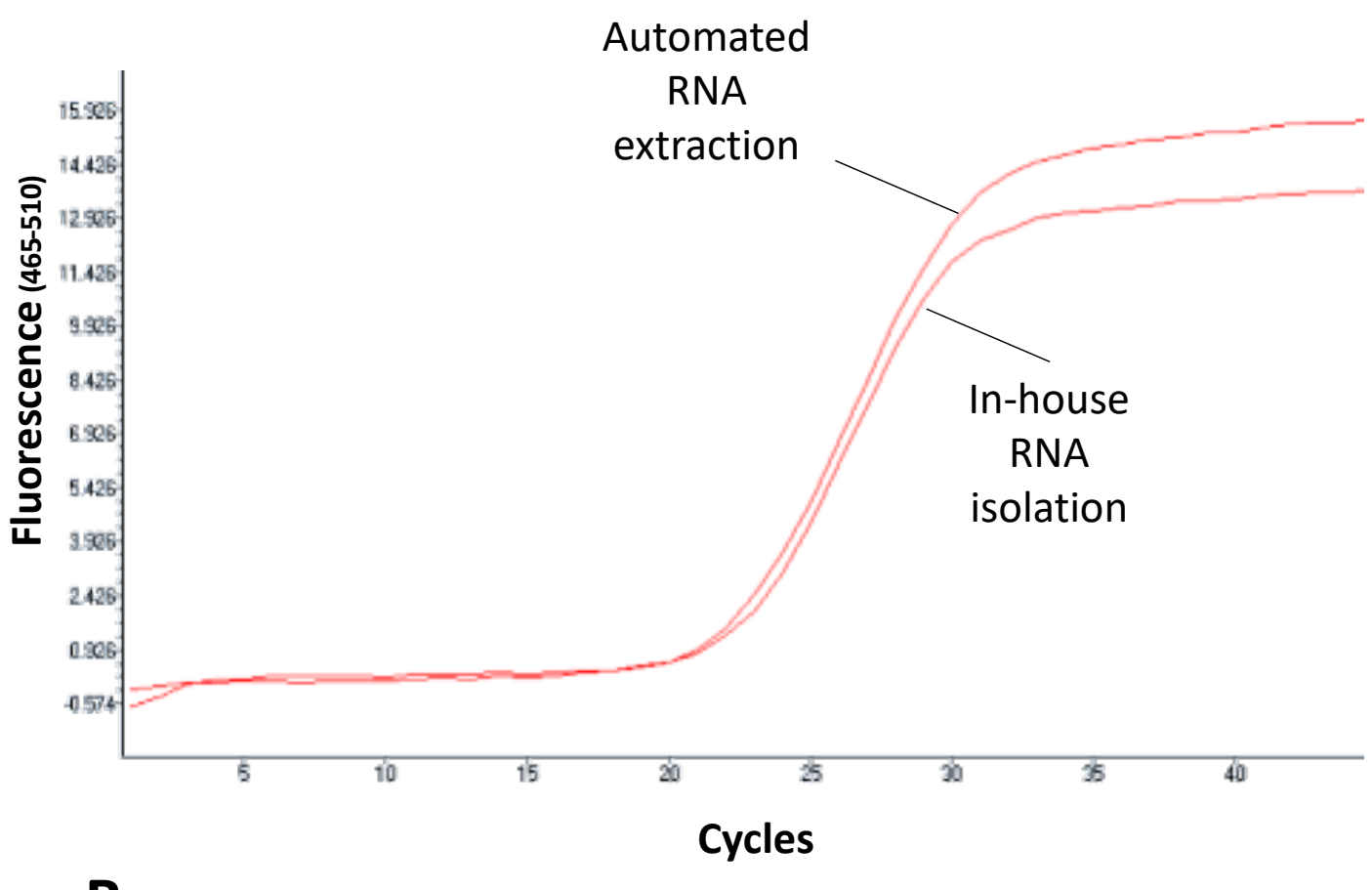

B

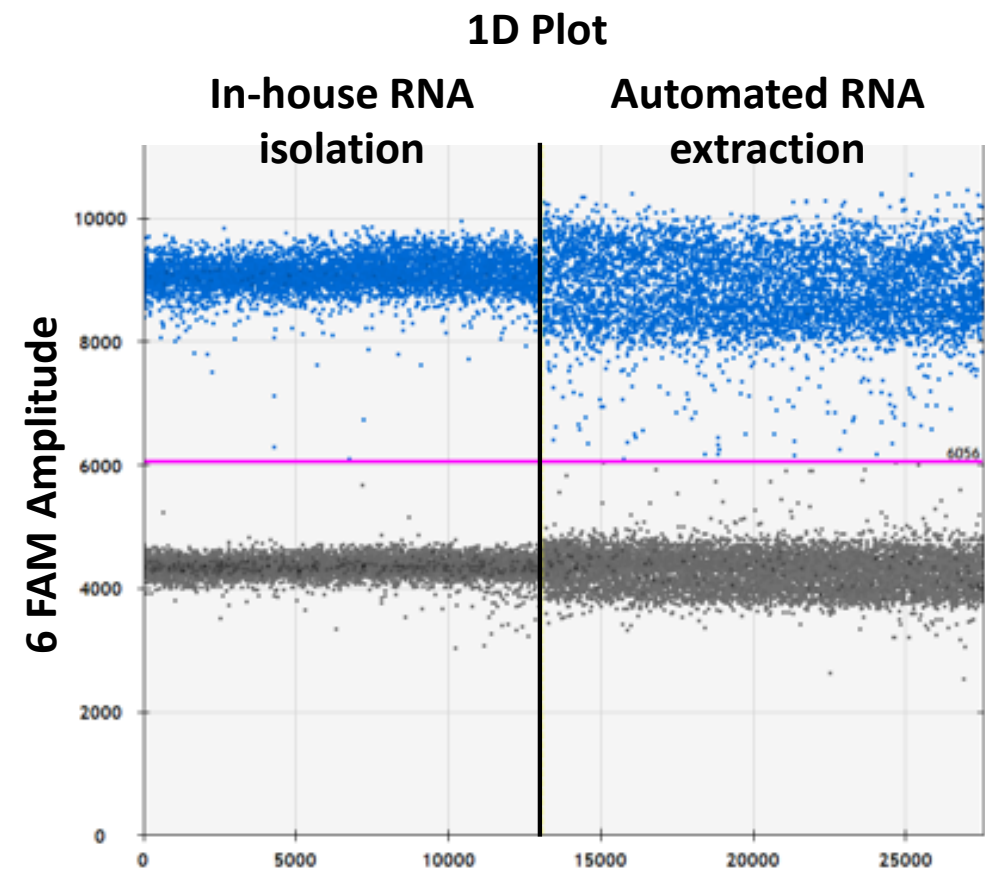

Events 
medRxiv preprint doi: https://doi.org/10.1101/2020.04.06.20054114; this version posted April 11, 2020. The copyright holder for this preprint (which was not certified by peer review) is the author/funder, who has granted medRxiv a license to display the preprint in perpetuity.

It is made available under a CC-BY 4.0 International license.
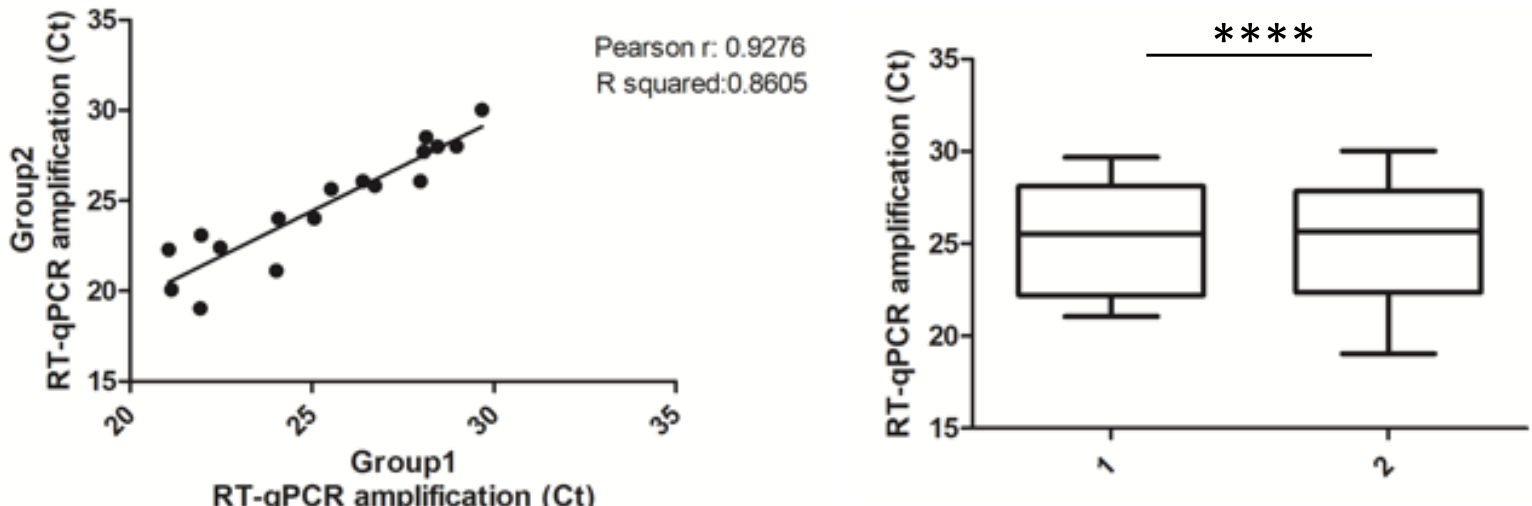

1: In-house RNA isolation

2: Automated RNA extraction 
medRxiv preprint doi: https://doi.org/10.1101/2020.04.06.20054114; this version posted April 11, 2020. The copyright holder for this preprint (which was not certified by peer review) is the author/funder, who has granted medRxiv a license to display the preprint in perpetuity.

It is made available under a CC-BY 4.0 International license .

A

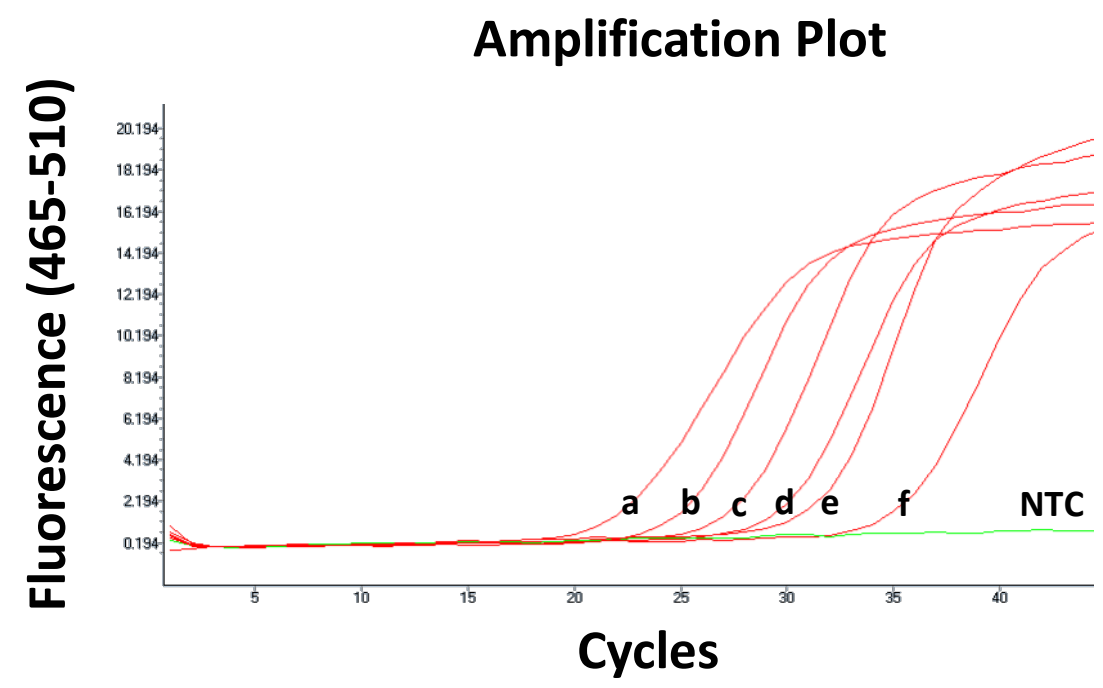

B

1D Plot

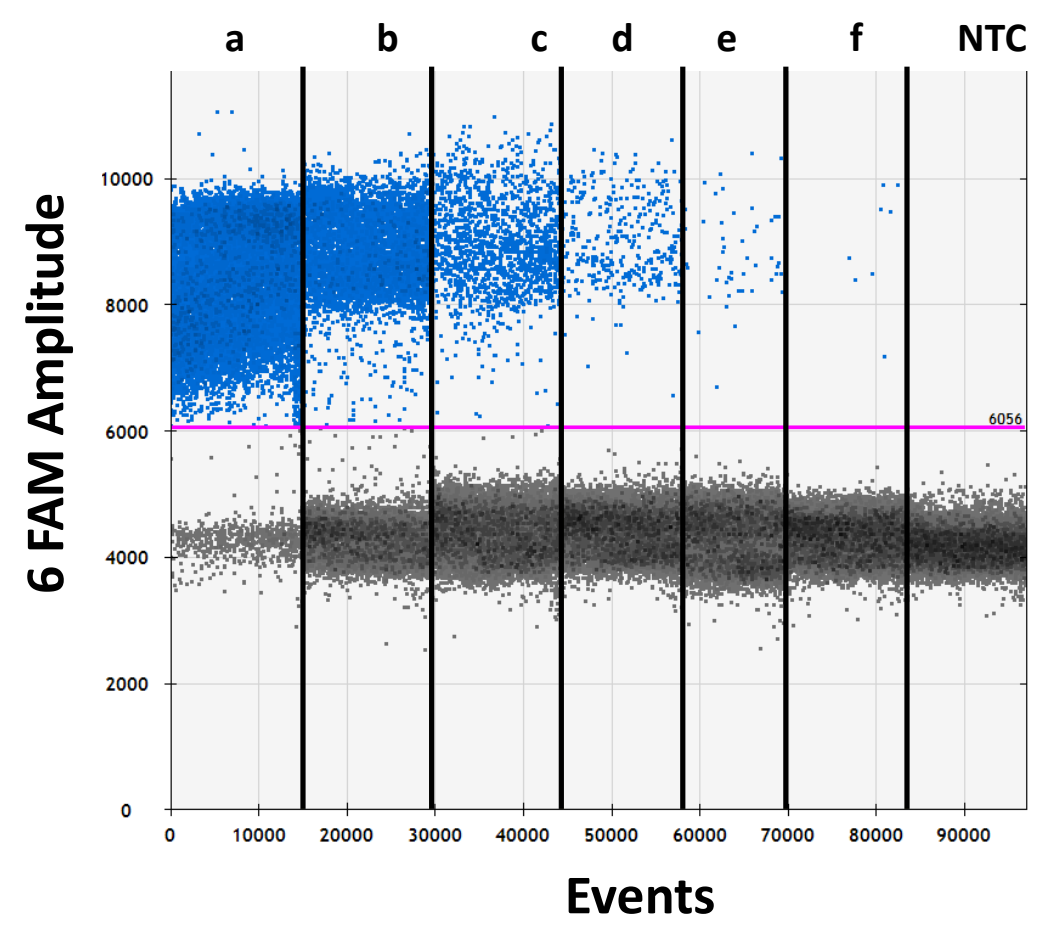

